\title{
The Position of Rural Farmer's Agricultural Storage Facilities for Yam Tuber Preservation in Ebonyi State
}

\author{
Ogba Ernest Ituma
}

\author{
Department of Technology and Vocational Education. \\ Ebonyi State University, Abakaliki-Nigeria
}

\section{Doi:10.5901/jesr.2013.v3n5p155}

\begin{abstract}
This study aimed at determining the position of Agricultural storage facilities available for storing yam tubers in Ebonyi State of Nigeria. Ebonyi State is one of the states in the South Eastern Geopolitical zone of the country. The design of the study is descriptive survey research design. The study has a population of eight thousand, four hundred and thirty $(8,430)$ rural farmers, sample for the study was one hundred and fifty (150) rural farmers. Random sampling technique was used in selecting 150 rural farmers in the State. Structured questionnaire was used and administered on the sample. One hundred and twenty (120) questionnaires was completed and returned. The data collected was analyzed using means and standard deviation. The result show that only Ban, underground pits, shades, leaves, grasses among others were used in storing yam tubers, which was traditional system. That huge economic loss are incurred by rural farmers, since, such materials have no protective value against, insects, fungi, Nematodes, virus, bad weather, bacteria attack. That rural farmer has no alternative than to use them since Educational development, technological innovation and scientific approach have not produced or developed yam tuber storage facilities. That will be used by the rural farmers in storing their yam tubers in Ebonyi State.
\end{abstract}

\section{Introduction}

Education is the key to human efforts in struggling, planning implementation and successful contribution to the up-liftment of any society in Nigeria. Ogba, (2009). Education in the view of Alumode (2010) is the ways every society can bring up their children to live well and attain their goals, values, belief, skills, attitude and knowledge without formal institutions (Indigenous). In another development, Ocho, (2005). Stressed that education is the process for involving people in the society effectively as a moral agent with the powers of surviving and contributing to the development of the society (formal). Therefore, Education in this study implies the skills, knowledge, attitude and values needed for providing agricultural storage facilities to the rural farmers for storing or preserving their yam tubers produced in Ebonyi State. Ugwu (2005) in his own view explained yam tubers' storage facilities as farm structures, which include Ban and underground Pit, He, Described ban and underground pits as primitive, traditional, lack scientific background to prevent disease attack on yam tubers. He maintains that ban, underground pits, cannot pro-long yam tubers life span to avoid artificial scarcity, hunger, and encourage farmer economic wellbeing in the state. However yam is called discorea Spp. with good six varieties in Ebonyi State, as follows: discorea rotundata, (white yam) Discorea Cayenesis (Yellow Yam) Discorea Alata (Water Yam). Discorea Dumentaorum (Three Leaf Yam) Discorea Bulbferia, (Aerial Yam) and Discorea Esculentum (Chinse Yam). Yam tubers are popular food stuff in Ebonyi State, Nigeria in general. It is staple food which is prepared in many ways for human consumption (Ukwa, (2012). Therefore, Development in the view of Ogba, (2012) is about having new things in addition 
to the old one that makes life more meaningful. To the society such as light (Electricity) good road network, information network, Health care, security of food, and human life development. He stressed that development bring about good education that can improve the level of yam tubers storage facilities to the rural farmers in Ebonyi State. The position of Agricultural storage facilities in this contest implies the situation in which yam tubers were exposed to a terrible condition without developing or producing any scientific or technological facilities for storing yam tubers in in addition to the traditional system available in the State. Adedeji (2010) maintains that the position of yam tuber storage, needs, good education and development in Ebonyi State. This is to make life of the rural farmers that produces yam tubers more meaningful in the society. He stress that their economic wellbeing impinges on good storage facilities and prevent Nematode attack, Bacteria, virus, fungi insects and undesirable weather condition to reduce yam tuber deterioration. Nweke (2010) explained that Nigerian investment in education has not done much development on agricultural storage facilities, since, Ban and underground pit that still remains primitive, traditional and unscientific for storing yam tuber in Ebonyi State.

BAN (Yam Tubers tied in Racks in the Ban)

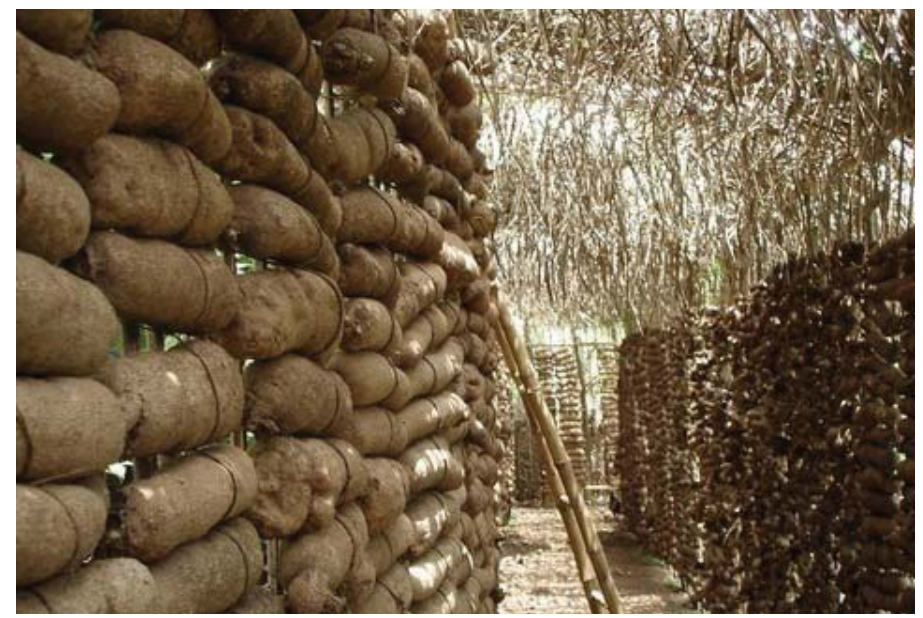

\section{Statement of the Problem}

Education, which is the key to skills, knowledge, and infrastructural development, has created a big gap in the position of Agricultural storage facilities for preserving yam tubers in the State. However, the investment of Ebonyi State in Education for infrastructural development requires serious attention in preserving yam tubers. Hence, the worries of the researcher are that education which is an instrument for infrastructural facilities development seems not to have reached yam tubers preservation and storage in Ebonyi State. Beside, Ebonyi State is one of the food baskets of the Nation, as well, as salt of the Nation. This implies that rural farmer in Ebonyi State requires good storage facilities to prevent insect attack, bacteria, virus, Nematodes, fungi; bad weather condition, to reduce yam tubers decay. This will boost economic wellbeing of the rural farmers and reduce huge economic losses, hunger, artificial scarcity and poverty among rural farmers in the State.

\section{Purpose of the Study}

The purpose of the study was to determine the available Agricultural storage facilities for preserving yam tubers produced by rural farmers in Ebonyi State.

Specifically, the study tends to: 
1. Determine the extent of agricultural storage facilities available in the rural areas for farmers to preserve their yam tubers.

2. Determine the extent of economic losses from yam tuber deterioration to the rural farmers in Ebonyi State.

3. Determine the extent of social and cultural attributes to yam tubers storage facilities in Ebonyi State.

\section{Research Questions}

The following research questions were posed to guide the study:

1. What are the extents of agricultural storage facilities available in the rural areas for farmers to preserve their yam tubers.

2. What are the extents of economic losses from yam tubers deterioration to the rural farmers in Ebonyi State.

3. What are the extents of social and cultural issues as related to yam tubers storage facilities in Ebonyi State.

\section{Methodology}

The design of the study is descriptive survey research, design. The area of the study is Ebonyi State of Nigeria. Which, is one of the states in the south Eastern Geo-political zone of Nigeria. The population for the study was 8,430 rural farmers that produce yam-tubers in Ebonyi State. (Statistical digest, 2012). The sample for the study was one hundred and fifty rural farmers that participate affectively in yam-tuber production in Ebonyi State. Stratified random sampling technique was used in selecting the sample. The researcher developed an instrument called the position of rural farmers Agricultural storage facilities for yam tubers preservation in Ebonyi State (TPRFASFYTP). The instrument has four point rating scale of high extent (HE) moderate extent (ME) low extent (LE) and very low extent (VLE). The instrument was validated by three experts one in measurement and evaluation in science education department and two in agricultural education option in the department of technology and vocational education of the same faculty and university. The instrument was tested using Cronback alpha. The reliability coefficient was 0.76 which was good enough to be used in the study. The instrument was administered to the respondents with the help of two research assistant one in each education zone. While the researcher covered one education zone (Ebonyi North, South and Central) during Ebonyi farmers show day. One hundred and twenty (120) questionnaires were completed and returned out of one hundred and fifty (150) distributed. While the data collected were analyzed using mean scores and standard deviation means score from 2.50 and above were regarded as high extent. While below 2.50 were regarded as low extent.

Research Question 1: What are the extents of available Agricultural storage facilities, for farmers to preserve their yam tubers in Ebonyi State.

Table 1: Available Agricultural Storage Facilities for Yam Tubers

\begin{tabular}{|c|l|c|c|c|}
\hline S/N & \multicolumn{1}{|c|}{ Constructs } & $\mathbf{X}$ & SD & Remark \\
\hline 1 & $\begin{array}{l}\text { After yam tuber harvest, they are stored in } \\
\text { underground pit. }\end{array}$ & 2.84 & 0.22 & High extent \\
\hline 2 & $\begin{array}{l}\text { Harvested yam tubers can be stored under the } \\
\text { shade in the farm. }\end{array}$ & 2.51 & 026 & High extent \\
\hline 3 & $\begin{array}{l}\text { Harvested yam tuber can be arranged and } \\
\text { covered with grasses, palm frond leaves and left } \\
\text { in the farm. }\end{array}$ & 2.65 & 0.25 & High extent \\
\hline 4 & Harvested yam tubers can be transported to the & 2,59 & 0.24 & High extent \\
\hline
\end{tabular}




\begin{tabular}{|c|l|c|c|c|}
\hline & farmer's house into his ban. & & & \\
\hline 5 & $\begin{array}{l}\text { Harvested yam tubers can be tied to sticks in } \\
\text { the ban (racks) }\end{array}$ & 2.50 & 0.20 & High extent \\
\hline 6 & $\begin{array}{l}\text { Harvested yam tuber can be stored in raised } \\
\text { bed constructed in the ban. }\end{array}$ & 3.34 & 0.27 & High extent \\
\hline 7 & $\begin{array}{l}\text { Harvested yam tubers can be stored in rooms in } \\
\text { the house with long planks on the ground. }\end{array}$ & 2.76 & 0.21 & High extent \\
\hline 8 & $\begin{array}{l}\text { Harvested yam tubers can be stored on the tree } \\
\text { branches up }\end{array}$ & 3.05 & 0.21 & High extent \\
\hline 9 & Harvested yam tubers can be stored in the bags & 3.05 & 0.25 & High extent \\
\hline 10 & $\begin{array}{l}\text { All these yam tubers method of storage are } \\
\text { traditional. }\end{array}$ & 2.50 & 0.21 & High extent \\
\hline
\end{tabular}

Table 1 show that all the items statement was accepted since; it has mean score above 2.50 , which is the cut off. This implies that it appeals to the available agricultural storage facilities for yam tubers in Ebonyi State.

Research Question 2: what are the extents of Economic loss from yam tubers deterioration to the rural farmers in Ebonyi State.

Table 2: Extent of yam tubers losses Response options

\begin{tabular}{|c|l|c|c|c|}
\hline S/N & \multicolumn{1}{|c|}{ Constructs } & X & SD & Rmark \\
\hline 1 & $\begin{array}{l}\text { Wet and dry rot as an economic loss from yam } \\
\text { tuber. }\end{array}$ & 3.52 & 0.28 & High extent \\
\hline 2 & $\begin{array}{l}\text { Insect bites and hole burrow on yam tuber as an } \\
\text { economic loss. }\end{array}$ & 2.58 & 0.21 & High extent \\
\hline 3 & $\begin{array}{l}\text { Nematodes attack on yam tuber as an economic } \\
\text { losses. }\end{array}$ & 3.18 & 0.24 & High extent \\
\hline 4 & $\begin{array}{l}\text { Brusses and spoilages on the skin of yam tuber as an } \\
\text { economic losses. }\end{array}$ & 2.53 & 0.21 & High extent \\
\hline 5 & $\begin{array}{l}\text { Fungi attack on the skin blister of yam tuber as an } \\
\text { economics loss. }\end{array}$ & 3.10 & 0.23 & High extent \\
\hline 6 & $\begin{array}{l}\text { Bacteria attack on yam tuber tissue rot as an } \\
\text { economics loss. }\end{array}$ & 2.81 & 0.21 & High extent \\
\hline 7 & $\begin{array}{l}\text { Yam tuber loss per an average farmer is about N1. } \\
5 m \text { in a year as an economic losses. }\end{array}$ & 2.63 & 0.20 & High extent \\
\hline
\end{tabular}

From table 2 it shows that all the item statements has mean scores above the cut off 2.50 . This indicates that it appeals to yam tuber economic losses to small farmers in Ebonyi State.

Research Question 3: What are the extents of social and cultural issues as related to yam tuber storage facilities in Ebonyi State.

Table 3: Culture and Social Issues in Yam Tuber Storage Response option

\begin{tabular}{|c|l|c|c|c|}
\hline $\mathbf{S / N}$ & \multicolumn{1}{|c|}{ Constructs } & $\mathbf{X}$ & SD & Remark \\
\hline 1 & Traditional culture may be preferred to new technology & 2.77 & 0.21 & High extent \\
\hline 2 & $\begin{array}{l}\text { Traditional system may be cheaper for them than spending } \\
\text { money to get modern storage facilities. }\end{array}$ & 2.73 & 0.21 & High extent \\
\hline 3 & $\begin{array}{l}\text { Social awareness of rural farmers on storage facilities may } \\
\text { be on poor education. }\end{array}$ & 3.53 & 0.28 & High extent \\
\hline 4 & $\begin{array}{l}\text { Information education dissemination to rural farmers in } \\
\text { Ebonyi State may be poor. }\end{array}$ & 3.10 & 0.23 & High extent \\
\hline
\end{tabular}




\begin{tabular}{|c|l|c|c|c|}
\hline 5 & $\begin{array}{l}\text { The desire to keep traditional method of their fore-father } \\
\text { with yam tuber storage facilities may be the cause for non- } \\
\text { request for modern method. }\end{array}$ & 2.59 & 0.24 & High extent \\
\hline 6 & $\begin{array}{l}\text { The attributes given to yam-tuber as chief crop, may have } \\
\text { social effect in their storage facilities. }\end{array}$ & 3.05 & 0.25 & High extent \\
\hline 7 & $\begin{array}{l}\text { The idea of modern storage facilities to the rural farmers } \\
\text { for yam tuber may not protect traditional practices. }\end{array}$ & 2.84 & 0.22 & High extent \\
\hline
\end{tabular}

Table 3 show that all the item statements mean score from 1 - 7 were above the cutoff point of 2 . 50. This simple implies that all the statement applied to cultural and social issues as related yam tuber storage in Ebonyi State.

\section{Discussion of the Findings}

With reference to the research question 1: which thought information on the available agricultural storage facilities for preserving yam tubers in Ebonyi State. Finding indicated that underground pit, shade, grasses, palm frond leaves, Ban, racks, beds, rooms tree branches, bags, were used as storage facilities for storing yam tubers. From the result all the items were traditional system of storing yam tubers. This finding is in line with the study of Ugwu (2005) who found that underground pit, bans among others as traditional, primitive and lack scientific background. He indicated that such storage facilities has no protective value for preventing the yam tubers from been attacked by many variable factors such as insects, fungi, bacteria, nematodes bad weather condition among other. He stress that this poor protective value lead to deterioration of yam tubers, and cause scarcity of yam tubers during the period of its high demand.

From research questions 2: which sought information on economic losses from yam tubers deterioration to the rural farmers in Ebonyi State. Findings indicates that aspect of economic losses include wet and dry rot, insect bits, nematode hole burrow, brusses, spoilage, skin blister, tissue rot, among others. The findings show that an average farmer loss about N1.5m in a year as an economic losses. This finding was in line with the study of Okafor (2009) who found out that large economic losses incurred by the rural farmers in yam tubers. As a result of using traditional system of yam tuber storage facilities, which do not have any protective value. He stresses that innovation, scientific approach and technological packages are needed to be introduced as modern storage facilities, to pro-long yam tuber life span.

From research question 3 which sought information on social and cultural issues as related to yam tuber storage facilities in Ebonyi State. The findings indicated that traditional value, less money spending on traditional method of storage, poor education, unawareness, inadequate information education, desire to keep traditional practices, yam as chief crop, were attribute to the use of primitive storage facilities for preserving yam tuber in Ebonyi State. This findings is in line with the study of Okorie (2004) who found out that poor scientific approach to yam tuber storage facilities, created gap in the wellbeing of farmers. He stress that farmers have no alternative in storing their yam tubers, since technology and science has not developed any good storage facilities for them. He contested that rural farmers should have been using modern storing facilities assuming modern storage facilities were available within their area of jurisdiction.

\section{Major Findings}

1. That an average rural farmer in Ebonyi has an economic loss of estimated cost of N1.5m in yam tuber deterioration, as result of using ban and underground pit for storage of yam tubers, which is unscientific.

2. That only ban, underground pit, leaves, shade, tree branches, palm frond leaves among other were the available Agricultural storage facilities for yam tuber. 
3. That rural farmers use traditional system of yam tuber storage facilities, because, they have no alternative since science and technology has not developed modern method for storing yam tubers.

\section{Recommendations}

The following recommendations were made base on the findings of the study. That government should direct their attention to the development of modern storage facilities for yam tubers produced in the rural Area of Ebonyi State. That, science and technology need to provide functional Agricultural storage facilities for yam tubers. That rural farmers should not be scared away, because of this problem, since it will be solved sooner or later.

\section{Conclusion}

Rural farmers who are mangers of their farm plots, should have being rich like other manager in companies and parastatal. If rural farmers had good storage facilities for preserving their yam tubers, only to sell them at the time of tis scarcity, improve on their economic wellbeing; build good houses, drive cars and many other good things. This indicate that rural farmers, should have being good job for many people to join farmer.

\section{References}

Ogba E.I. (2009) The Challenges of Crop Production in Nigeria, for the 21st Century. Journal of Tropical Agricultural, Food Environment and Extension, 1(2) 5 - 8.

Ogba, E.I. (2012) The New Generation Agricultural Science for Secondary Schools. Enugu, Immaculate Publisher.

Alumode B.E. (2010). Education for National Development in the 21st Century Nigeria ESUT J ournal of Education, 5(2) $252-253$.

Ocho L.O. (2005) The History of Nigeria Education. Enugu

Ugwu O.I. (2005) Crisis and Stress in Agricultural Storage Facilities in Nigeria Enugu Noble Press.

Ukwa S.O. (2012) Agricultural Management guide to Entrepreneurship, Onitsha. Sucky Press.

Adediji, F.O. (2010) The Challenges of Agricultural Production in the 21st Century Nigeria. Journal of Agricultural Science, 5(3) $15-25$.

Nweke B.O. (2010) The Development of Agricultural in West African Countries. Onitsha, Party Press.

Okafor, P.I. (2009) Effective Vocational and Technology Education, in Developing Country. Onitsha, Sucky Press.

Okorie J.U. (1981) Fundamentals of Teaching in Nigeria. fourth Dimension Publisher. 